\title{
Gerakan Percepatan Penganekaragaman Konsumsi Pangan (P2KP) Untuk Antisipasi Dampak Perubahan Iklim Pada Sektor Pertanian
}

\author{
Lolita Endang Susilowati*, Uyek Malik Yakop, Bambang Hari Kusumo \\ Program Studi Ilmu Tanah Fakultas Pertanian Universitas Mataram, Indonesia
}

\begin{abstract}
Article history
Received: 09 Desember 2019

Revised: 27 Januari 2019

Accepted: 26 Maret 2020

*Corresponding Author:

Lolita Endang Susilowati Program Studi Ilmu Tanah Fakultas Pertanian Universitas Mataram, Mataram, Indonesia Email:

lolitaabas37@unram.ac.id
\end{abstract}

Abstract: Climate change causes changes in rainfall patterns that is high intensity rain in a short duration. This situation could threaten the agricultural sector which impacts on national food security and food fulfillment for each household. Therefore, it is necessary to introduce an effective strategy to meet household food needs through the P2KP movement in dealing with the threat of climate change. This community service aims to: (1) providing an understanding of climate change and its impact on the food agriculture sector to the community; (2) socializing the "P2KP movement" accompanied by a demonstration plot of the use of house yards for cultivation of vegetables in pots. These community service activities implement a participatory pattern, in which the target community was involved in every decision making both in preparing, implementing, and evaluating the program activities. The results of the community service activities shows that the target community's knowledge of climate change and its impact on the agricultural sector has been successfully improved. The P2KP movement has been socialized and received a positive response from the target community, then they a;ready known to optimizing the use of home yards for cultivation of plants in pots becomes an alternative agricultural system that is resilient in the face of climate change.

Keywords: community services; nutrition; participation; the yard; vegetable

Abtrak: Perubahan iklim menyebabkan perubahan pola hujan, yaitu hujan berintensitas tinggi dalam waktu yang singkat. Keadaan ini dapat mengancam sektor pertanian yang berdampak pada ketahanan pangan nasional dan pemenuhan kebutuhan pangan setiap rumah tangga. Karenanya, kepada masyarakat perlu dikenalkan strategi yang efektif untuk memenuhi kebutuhan pangan yang seimbang dan bergizi melalui gerakan P2KP dalam menghadapi ancaman perubahan iklim. Pengabdian kepada masyarakat ini bertujuan: (1) memberikan pemahaman kepada masyarakat tentang perubahan iklim dan dampaknya di sektor pertanian pangan; 2) mensosialisasikan "gerakan P2KP" disertai dengan demplot pemanfaatan pekarangan rumah menjadi lahan produktif untuk budidaya tanaman sayuran. Kegiatan ini menerapkan pola pendekatan partisipatif dimana masyarakat sasaran dilibatkan secara aktif mulai dari penyusunan rencana pelaksanaan kegiatan, pelaksanaan kegiatan dan evaluasi kegiatan. Hasil kegiatan pengabdian menunjukkan bahwa telah berhasil meningkatkan pengetahuan masyarakat sasaran dalam hal perubahan iklim dan dampaknya terhadap sektor pertanian. Sosialisasi gerakan P2KP telah medapat respon positif dari masyarakat sasaran dan mampu mengoptimalkan pemanfaatan lahan pekarangan untuk lahan budidaya tanaman sebagai alternative sistem pertanian yang tangguh dalam mengantisipasi dampak perubahan iklim pada sektor pertanian.

Kata Kunci: gizi; partisipasi; pekarangan; pengabdian masyarakat; sayuran 


\section{PENDAHULUAN}

Perubahan iklim di antaranya adalah terjadi perubahan pola curah hujan (intensitas hujan tinggi akan tetapi jumlah hari hujan akan semakin pendek), musim kemarau yang panjang, naiknya muka air laut, suhu udara, dan peningkatan kejadian iklim ekstrim yang menyebabkan banjir dan kekeringan. Perubuhan iklim ini dapat mengancam ketahanan pangan nasional baik tersedianya pangan yang cukup dan terpenuhinya kebutuhan pangan setiap rumah tangga untuk menjalani hidup yang sehat dan aktif.

Masyarakat Indonesia dengan sumber pangan utamanya adalah beras akan menghadapi ancaman kecukupan beras akibat perubahan iklim, disamping semakin menyempitnya luas lahan produktif akibat alih fungsi lahan ke usaha non pertanian. Tanaman padi merupakan tanaman pangan yang sangat peka terhadap ketersediaan air, sementara perubahan iklim telah mengakibatkan perubahan pola hujan yang tidak menentu. Sebagai akibatnya, produksi padi nasional akan terus menurun, sementara jumlah penduduk akan terus meningkat.

Dalam rangka mengurangi ketergantungan masyarakat terhadap beras, sejak repilita VI (tahun 1994-1999) pemerintah telah mengeluarkan kebijakan penganekaragaman konsumsi pangan berbahan pangan non beras dengan program diversifikasi pangan dan gizi. Selanjutnya untuk percepatan tercapainya tujuan dari program diversifikasi pangan dan gizi, tahun 2009 pemerintah mengeluarkan PP No. 22 Tahun 2009 tentang Kebijakan Percepatan Penganekaragaman Konsumsi Pangan Berbasis Sumberdaya Lokal. Akan tetapi tujuan dari program penganekaragaman pangan tersebut belum juga tercapai. Karenanya untuk mempercepat tercapainya tujuan dari program penganekaragaman konsumsi pangan, pada tahun 2015 pemerintah mengeluarkan kebijakan percepatan penganekaragamankonsumsi pangan (P2KP) dengan dikeluarkannya Permentan no 18 tahun 2015 tentang Gerakan P2KP. Gerakan P2KP diimplementasikan melalui kegiatan: (1) sosialisasi dan promosi P2KP (Permentan no 18 tahun 2015); (2) optimalisasi pemanfaatan pekarangan sebagai lahan budidaya aneka jenis tanaman.

Mengacu pada uraian di atas, maka telah dilakukan kegiatan pengabdian kepada masyarakat dengan tujuan: (1) memberikan pemahaman kepada masyarakat tentang perubahan iklim dan dampaknya di sektor pertanian pangan; (2) mensosialisasikan "gerakan P2KP" disertai dengan demplot pemanfaatan pekarangan rumah menjadi lahan produktif untuk budidaya aneka jenis tanaman sayuran. Melalui kegiatan pengabdian ini diharapkan masyarakat segera termotivasi untuk memanfaatkan lahan pekarangan rumah sebagai lahan budidaya tanaman sayuran untuk memenuhi pergesera kebutuhan pangan dan gisi masyarakat akibat perubahan iklim.

\section{METODE}

Kegiatan pengabdian ini dilaksanakan dari bulan Juni s/d November 2017 di Desa Narmada, Kecamatan Narmana, Kabupaten Lombok Barat. Sebagai masyarakat sasaran adalah masyarakat Dusun Kantar I dan II Desa Narmada. Kegiatan ini menerapkan pola pendekatan partisipatif dimana masyarakat sasaran dilibatkan secara aktif pada setiap tahap kegiatan mulai dari penyusunan rencana pelaksanaan kegiatan, pelaksanaan kegiatan dan evaluasi kegiatan.

Penyusunan rencana kegiatan dilakukan dengan diskusi kelompok terarah (Focus Group Discussion, FGD), dihadiri oleh tim pengabdian dan masyarakat sasaran. Tujuan dari FGD adalah (1) membangun kesamaan persepsi dan tujuan dari kegiatan pengabdian ini; (2) mensepakati jadwal dan 
lokasi kegiatan meliputi kegiatan penyuluhan, kegiatan sosialisasi, dan demplot pemanfaatan pekarangan rumah serta jenis tanaman sayuran yang diusahakan; 3) Mensepakati bentuk kerjasama dalam hal tanggung jawab kegiatan, kontribusi anggaran dan kepemilikan hasil tanaman

Program pengabdian ini memiliki tiga kegiatan, meliputi:

1. Penyuluhan mengenai perubahan iklim akibat pemanasan global dan dampaknya di sektor pertanian tanaman pangan. Sebagai peserta penyuluhan adalah ibu rumah tangga, kader lingkungan dan staf desa dengan total peserta penyuluhan sebanyak 20 orang. Sebagai narasumber adalah BH Kusumo.

2. Sosialisasi program "gerakan P2KP" kaitannya dengan perubahan iklim. Sebagai peserta penyuluhan adalah ibu rumah tangga, kader lingkungan dan staf desa dengan total peserta penyuluhan sebanyak 20 orang. Sebagai narasumber adalah Uyek Malek Yakop

3. Bimbingan teknis dan pendampingan pemanfaatan pekarangan rumah menjadi lahan produktif untuk budidaya aneka ragam jenis tanaman sayuran dalam pot. Demplot pemanfaatan pekarangan untuk lahan budidaya tanaman dalam pot dilaksanakan di rumah kepala desa. Masyarakat sasaran mendapatkan bimbingan teknis mulai dari pengadaan pupuk organik berbahan baku limbah organik rumah tangga dengan metode pengomposan menggunakan mikroorganisme lokal (MOL), pengadaan dekomposer MOL, penyiapan media tanam dalam pot, penyediaan bibit tanaman, pemiliharaan tanaman dan panen. Sebagai penanggung jawab kegiatan adalah Lolita Endang Susilowati dibantu oleh anggota tim dan mahasiswa KKN yang kehadirannya bertepatan dengan waktu kegiatan bintek dan pendampingan.

\section{HASIL DAN PEMBAHASAN}

\section{Kegiatan penyuluhan.}

Kegiatan penyuluhan diawali dengan pemaparan materi dilanjutkan dengan diskusi dan tanya jawab serta pada akhir waktu penyuluhan dilakukan evaluasi atas respon petani terhadap materi penyuluhan (Gambar 1). Dari sesi diskusi dan tanyajawab dapat digambarkan bahwa masyarakat sasaran menunjukkan partisipasi tinggi dalam mengikuti penyuluhan. Hal ini ditunjukan dengan adanya beberapa pertanyaan yang diajukan oleh peserta penyuluhan.kepada narasumber.
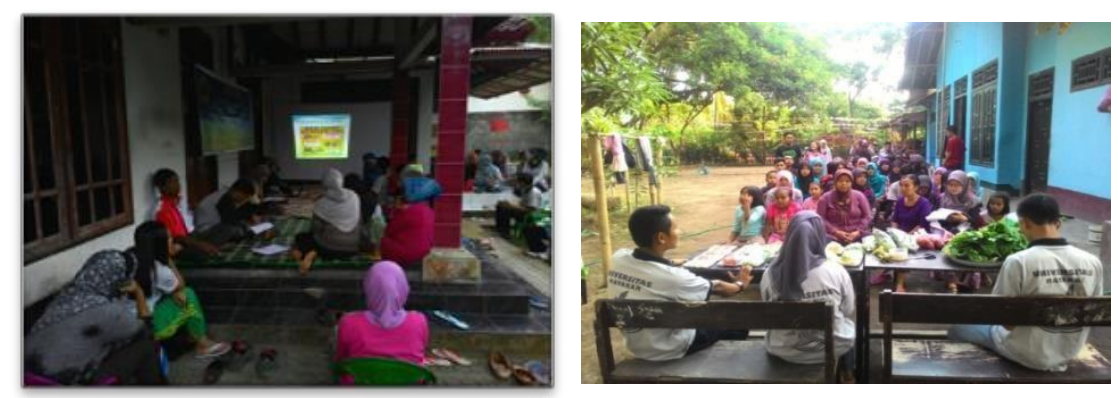

Gambar 1. Suasana penyuluhan di Dusun Kantar 1 dan Kantar 2.

Beberapa bentuk pertanyaan yang diajukan oleh peserta penyuluhan perubahan iklim di antaranya:

1. Seberapa besar dampak perubahan iklim terhadap sektor pertanian. Kepada peserta diberikan penjelasan sebagai berikut. Besarnya dampak perubahan iklim terhadap pertanian sangat 
bergantung pada (a) tingkat dan laju perubahan iklim dan (b) ketahanan sistem produksi pertanian. Persoalannya tidak hanya terbatas pada besarnya dampak yang dimunculkan, akan tetapi secara pasti perubahan iklim merupakan satu ancaman yang sangat serius terhadap sektor pertanian dan potensial mendatangkan masalah baru bagi keberlanjutan produksi pangan. Perubahan iklim mengakibatkan terjadi pergeseran pola dan waktu hujan. Empat sd lima puluh tahun yang lalu, permukaan bumi ini menerima pola hujan berintensitas rendah dengan durasi hujan berlangsung relative lama, sehingga sistem pertanian dapat memanfaatkan air hujan dalam kurun waktu yang relative laman. Sementara pola hujan saat ini, hujan berintensitas tinggi dengan durasi waktu sangat singkat dan waktu turun hujan berselang relative lama. Sebagai akibatnya, terjadi kekeringan dan pada saat hujan turun terjadi kebanjiran. Kedua keadaan ini berpengaruh negative terhadap sistem pertanian.

2. Selain factor hujan, apa saja dampak lain yang muncul akibat perubahan iklim yang berpengaruh pada sistem pertanian. Kepada peserta diberikan penjelasan, dampak lain yang muncul adalah peningkatan suhu udara global. Peningkatan suhu menyebabkan terjadinya peningkatan transpirasi yang selanjutnya menurunkan produktivitas tanaman pangan, meningkatkan konsumsi air, mempercepat pematangan buah/biji, menurunkan mutu hasil, dan mendorong berkembangnya hama penyakit tanaman. Berdasarkan hasil simulasi tanaman, kenaikan suhu sampai $2^{\circ} \mathrm{C}$ di daerah dataran rendah dapat menurunkan produksi sampai $40 \%$, sedangkan di dataran sedang dan tinggi penurunan produksi sekitar 20\% (Surmaini et al. 2008).

3. Bagaiman upaya kita menghadapi perubahan iklim kaitannya dengan usaha di bidang pertanian. Kepada peserta diberikan penjelasan sebagai berikut. Dampak perubahan iklim yang begitu besar merupakan tantangan bagi sektor pertanian. Peran aktif berbagai pihak diperlukan untuk mengantisipasi dampak perubahan iklim melalui upaya mitigasi dan adaptasi. Upaya antisipasi ditujukan untuk menyiapkan strategi mitigasi dan adaptasi. Teknologi mitigasi ditujukan untuk mengurangi fakor utama penyebab terjadi perubahan iklim. yaitu emisi gas rumah kaca (GRK). Teknologi mitigasi untuk mengurangi emisi GRK dari lahan pertanian antara lain dengan menggunakan varietas rendah emisi, membenahi teknologi pengelolaan air dan lahan seperti pengelolaan lahan pekarangan rumah menjadi lahan produktif dengan pola tanam dalam pot. Teknologi adaptasi bertujuan melakukan penyesuaian terhadap dampak dari perubahan iklim untuk mengurangi risiko kegagalan produksi pertanian. Teknologi adaptasi meliputi penyesuaian waktu tanam, penggunaan varietas unggul tahan kekeringan, rendaman, serta pengembangan teknologi pengelolaan air.

Terkait dengan kegiatan Sosialisasi program "gerakan P2KP” beberapa pertanyaan yang diajukan oleh peserta punyuluhan adalah:

1. Apa tujuan dari gerakan Percepatan Penganekaragaman Konsumsi Pangan (P2KP) ini. Kepada peserta diberikan penjelasan sebagai berikut. Gerakan P2KP merupakan salah satu upaya untuk mewujudkan peningkatan diversifikasi pangan. P2KP dilaksanakan dalam tiga bentuk kegiatan utama yaitu: (a) Optimalisasi Pemanfaatan Pekarangan melalui konsep Kawasan Rumah Pangan Lestari; (b) Pengembangan Pangan Lokal; serta (c) Promosi dan Sosialisasi P2KP. Kegiatan P2KP telah dilaksanakan sejak tahun 2010 hingga saat ini dengan berbagai sasaran dan capaian yang terus berkembang.

2. Apakah bisa dijelaskan pengertian mengenai konsep rumah pangan lestari. Kepada peserta diberikan penjelasan sebagai berikut. Konsep rumah pangan lestari merupakan model alternatif 
terobosan pembangunan pertanian untuk memanfaatkan lahan pekarangan rumah sebagai lahan budidaya ragam komoditas pertanian (komoditas tanaman, peternakan dan perikanan air tawar). Optimalisasi pemanfaatan pekarangan melalui konsep Rumah Pangan Lestari (RPL) untuk mewujudkan: (1) penganekaragaman pangan baik dari komoditas tanaman seperti: umbi-umbian, sayur-sayuran, buah-buahan, toga, dari komoditas peternakan seperti ayam buras dan dari komoditas perikanan, (2) dukungan dan pemenuhan pangan rumah tangga dalam pola konsumsi pangan yang beragam, bergizi dan aman. Tujuan jangka panjang dari pengembangan Rumah Pangan Lestari adalah : (1) Kemandirian pangan keluarga; (2) Diversifikasi pangan berbasis sumberdaya local; (3) Pelestarian tanaman pangan untuk masa depan; (4) Peningkatan kesejahteraan keluarga dan masyarakat

3. Bagaimana model yang tepat terkait dengan pemanfaatan pekarangan rumah yang tergolong sempit. Kepada peserta penyuluhan diberikan contoh model budidaya untuk Perumahan Tipe 21 (Total lahan sekitar $36 \mathrm{~m}^{2}$ ).

Model Budidaya: Vertikultur (model gantung, dan tempel)

Basis Komoditas: Sayuran: Sawi, Kucai, Pakcoi, Kangkung, Bayam, Kemangi, Caisim, Seledri, Selada Bokor, Bawang daun Toga: Kencur, Antanan, Gempur Batu, Daun Jinten, Sambiloto, Jahe merah, Binahong

Model Budidaya: Pot/ polybag

Sayuran: Cabai, Terong, Tomat, Buncis tegak Toga: Jahe, Kencur, Kunyit, Temu Lawak, Kumis kucing

Pada akhir penyuluhan dilakukan evaluasi atas materi yang disampaikan pada kegiatan penyuluhan. Evaluasi dilakukan dengan cara: tim pelaksana pengabdian memberikan soal kepada peserta penyuluhan untuk dijawab. Hasil penilaian menununjukan nilai rata-rata jawaban peserta atas pertanyaan yang diberikan seb elum dan sesudah penyuluhan terlihat bahwa pengetahuan peserta meningkat dari sebelum dan sesudah mengikuti penyuluhan. Rata-rata nilai sebelum penyuluhan adalah 35, kemudian meningkat menjadi 48 setelah mengikuti penyuluhan atau terjadi peningkatan pengetahuan sebesar $37,1 \%$. Hasil tersebut menunujukan peningkatan pengetahuan yang diterima oleh peserta penyuluhan belum optimal. Hal ini boleh jadi disebabkan (1) peserta penyuluhan memiliki tingkat pendidikan yang beragam; (2) peserta membutuhkan penjelasan berulang kali terkait dengan materi yang disampaikan; (3) teknik penyampaian materi boleh jadi kurang menarik bagi peserta.

\section{Kegiatan Bimtek}

Kegiatan bintek meliputi pembelajaran/ praktek langsung mengenai (1) pembuatan dekomposer berbasis mikroorganisme local (MOL); (2) pengomposan limbah organik rumah tangga dan (3) tehnik pembibitan dan menyiapan media tanam dalam pot. Pembelajaran praktis pembuatann dekomposer berbasis mikroorganisme lokal (MOL) diawali dengan penjelasan tentang (1) apa yang dimaksud drngan decomposer; (2) apa decomposer berbahan baku MOL; (3) apa peran decomposer MOL dalam pengomposan. Dekomposer adalah sekolompok mikroorgaganisme (bakteri, jamur dan aktinomisetes) yang berperan untuk mempercepat proses pembusukan bahan organik yang dikomposkan (Saraswati dkk, 2006).

Dekomposer MOL dapat dihasilkan dengan memfermentasi limbah organik-rumah tangga yang telah mengalami pembusukan dalam suatu medium buatan yang mengandung karbohidrat (Isroi, 2015). Wulandari dkk, (2009) menyebutkan MOL merupakan sekumpulan mikroorganisme 
yang bisa dikembangbiakkan dengan menyediakan sumber nutrisi dan berfungsi sebagai starter dalam pembuatan kompos.

Bimtek pembuatan MOL ditunjukan dalam Gambar 2. Sebagai bahan baku MOL antara lain nasi sisa, bonggol pisang, sisa-sisa sayur dan buah-buahan busuk yang tidak dikonsumsi. Contoh komposisi bahan untuk pembuatan MOL adalah $10 \mathrm{~kg}$ limbah sayuran hijauan (sawi, bayam, kol, brokoli, kangkung, caisim dll); garam $5 \%$ dari berat bahan; air cucian beras atau air kelapa 10 liter; gula merah/gula jawa $2 \%$ dari cairan yang peroleh setelah 3 minggu. Proses pembuatan MOL sebagai berikut: (1) haluskan limbah buah, kemudian masukan dalam ember; (2) masukkan air cucian beras/air kelapa kedalam ember plastik yang berisi buah-buahan tersebut, kemudian ember ditutup rapat, simpan di tempat yang tidak terkena sinar matahari langsung dan biarkan terfermentasi selama 15 hari; (3) saring cairan yang diperoleh biasanya berwarna kuning kecoklatan atau sesuai bahan sayurnya; (4) MOL buah sudah siap kita gunakan.
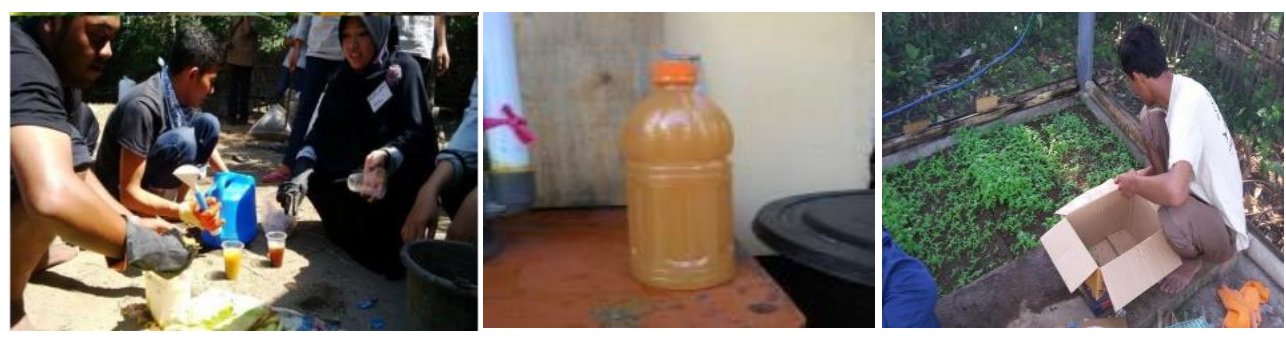

Gambar 2. Praktek pembuatan dekomposer MOL (kiri); decomposer hasil kegiatan (tengah), dan bimtek penyemaian bibit tanaman (kanan).

Bimtek pengomposan dengan dekomposer MOL ditunjukan dalam Gambar 2. Proses pengomposan dengan decomposer MOL hanya membutuhkan waktu sekitar 5-6 minggu, sementara pengomposan secara alami membutuhkan waktu 12 minggu.

Bahan baku kompos adalah limbah organic rumah tangga dan pupuk kandang dengan perbandingan 1:1. Susilowati, (2014) melaporkan bahwa dengan mengaplikasikan MOL dalam pengomposan dapat mempercepat proses penguraian sampah/limbah organik menjadi kompos dalam kurun waktu sekitar 1,5 bulan. Selama proses pengomposan juga teradi pengurangan volume tumpukan bahan hingga mencapai 50\% dari volume bahan awal. Pada saat itu, kompos mulai dapat dipanen dan dapat digunakan sebagai pupuk organik. Teknik pengomposan dengan dekomposer MOL sama dengan menggunakan dekomposer lainnya.

Bimtek penyemaian benih. Media untuk penyemaian terdiri dari tanah: pupuk kandang/kompos:arang sekam = 1:1:1. Untuk wadahnya bisa menggunakan bak, seed tray, atau wadah plastic atau menggunakan daun pisang. Wadah penyemaian diisi dengan media tanam kemudian diratakan. Buatlah lubang tanam dengan ukuran sekitar $0,5 \mathrm{~cm}$ untuk menyemai benih berukuran besar, sedangkan untuk benih berukuran kecil cukup dibuatkan alur saja pada media. Taburkan benih dan tutup dengan lapisan tipis tanah, siram secara teratur dan letakan pada lokasi yang teduh. Bibit yang siap ditanam adalah bibit yang memiliki daun utama minimal 3 helai daun pada umur 7-14 hari setelah semai.

Jika menggunakan daun pisang, daun pisang dibuat ukuran lebar 2-3 $\mathrm{cm}$ dan panjang $6 \mathrm{~cm}$. Kemudian daun pisang digulung menjadi bentuk tabung yang bagian atas dan bawahnya bolong. Lalu masukkan media tanam ke dalamnya. Selanjutnya benih ditanam secara langsung pada gulungan daun 
pisang tersebut sebanyak satu benih per gulungan hingga proses penanaman bibit. Keuntungan menggunakan cara ini adalah untuk meminimalisir kerusakan akar pada saat transpanting. Gambar 2 memuat gambar bimtek penyemaian bibit.

\section{Kegiatan pendampingan.}

Pendampingan demplot optimalisasi pemanfaatan lahan pekarangan sebagai lahan produktif. Pendampingan dilakukan mulai dari penyiapan media tanam, perawatan tanaman sampai dengan panen. Media tanam dalam polybag terdiri dari campuran tanah dan kompos dengan perbandingan 1:1 (Anonioum, 2012). Untuk pengendalian hama dan penyakit digunakan pestisida hayati (Basukriadi, 2008).

\section{Evaluasi Kegiatan}

Evaluasi terhadap kegiatan ini dilakukan oleh masyarakat sasaran dalam diskusi grup terarah (FGD). Kegiatan evaluasi dimaksudkan untuk menilai secara kualitatif mengenai respon masyarakat terhadap kegiatan pengadian kepada masyarakat. Hasil evaluasi menunjukkan ada respon positif dari masyarakaat sasaran. Hal ini ditunjukkan dengan tingkat partisipasi masyarakat sasaran yang cukup tinggi dalam setiap tahap kegiatan. Keingin tahuan masyarakat sasaran juga cukup tinggi, sebagaimana ditunjukkan dengan antosias masyarakat dalam mengikuti setiap kegiatan, serta keaktifan masyarakat sasaran untuk bertanya dan berdiskusi dengan tim pengabdian.

Persepsi masyarakat terhadap kegiatan pengabdian dapat dipilah menjadi 3 kelompok. Kelompok pertama adalah mereka yang menyatakan kegiatan pengabdian ini berkatagori baik dan sangat bermanfaat untuk menuhi diversivikasi pangan mengantisipasi perubahan iklim, jumlahnya ada 53 $\%$, yang menyatakan cukup baik ada $34 \%$ dan yang menyatakan kurang baik ada $13 \%$. Masyarakat sasaran yang menyatakan baik adalah mereka yang telah pernah mendapatkan informasi mengenai teknologi yang diintroduksi, sementara yang menyatakan cukup adalah kelompok mereka yang baru pengenal materi dan teknologi yang diintroduksi dan yang menyatakan kurang baik adalah mereka yang tidak peduli atas introduksi teknologi dimaksud.

Terkait dengan optimasi pemanfaatan pekarangan sebagai lahan produktif, masyarakat memiliki motivikasi yang beragam. Hal ini boleh jadi ada kaitannya dengan pengalaman hidup mereka, perbedaan wawasan dan/atau tingkat ekonomi masyaralat. Bagi masyarakat sudah terbiasa menerima transfer teknologi menunjukkan motivasi yang tinggi untuk menerapkan program pemanfaatan lahan pekarangan untuk gerakan P2KP menghadap dampak perubahan iklim. Dari hasil wawancara dengan masyarakat sasaran yang termotivasi untuk mengembangkan program optimalisasi pemanfaatan lahan pekarangan ada $10 \%$ dari 20 orang masyarakat sasaran secara mandiri.

\section{KESIMPULAN DAN SARAN}

Kegiatan pengabdian ini telah berhasil meningkatkan pengetahuan masyarakat sasaran dalam hal perubahan iklim dan dampaknya terhadap sektor pertanian tanaman pangan. Sosialisasi P2KP telah dilakukan dan medapat respon positif dari masyarakat sasaran. Gerakan P2KP melalui program optimasi pemanfaatan lahan pekarangan untuk lahan budidaya tanaman merupakan alternatif sistem pertanian yang tangguh dalam mengantisipasi dampak perubahan iklim pada sektor pertanian. Dari kegiatan pengabdian ini telah terbangun satu Demplot optimalisasi pemanfaatan lahan pekarangan sebagai lahan budidaya tanaman sayuran sistem tanam dalam pot. 


\section{DAFTAR PUSTAKA}

Anonim. 2012. Inovasi Terkini Budidaya Sayuran di Pekarangan Agroinovasi Sinar Tani Edisi 31. Oktober - 6 Nopember 2012 No.3480 Tahun XLIII. Badan Litbang Pertanian

Basukriadi, A. 2008. Pengendalian Hayati untuk Pengelolaan Hama http://repository.ut.ac.id/4456/1/BIOL4421-M1.pdf. Diakses 30 Desember 2017.

Isroi. 2015. Materi Resep Pembuatan Mikro Organisme Lokal (MOL). Posted on April

7, 2015 http://isroi.com/2015/04/07/materi- resep-pembuatan-mikro-organisme-lokal-mol/

Surmaini, E., Rakman, dan R. Boer. 2008. Dampak perubahan iklim terhadap produksi padi: Studi kasus pada daerah dengan tiga ketinggian berbeda. Prosiding Seminar Nasional dan Dialog Sumberdaya Lahan Pertanian. Balai Besar Penelitian dan Pengembangan Sumberdaya Lahan Pertanian, Bogor.

Susilowati, L.E. 2014. Teknologi Pengelolan Lahan Kering yang Ramah Lingkungan untuk Menghadapi Perubahan Iklim di Provinsi NTB. Disampaikan pada workshop teknologi pertanian ramah iklim "Indonesia Merespon Perubahan Iklim"BMKG-BPPT- DRNKementerian Pertanuian - PII.18 September 2014 di Jakarta. 